\title{
2 軸曲げを受ける SRC 長柱の耐力 STRENGTH OF A COMPOSITE LONG COLUMN SUBJECTED TO BI-AXIAL BENDING
}

\author{
柴田道生* \\ Michio SHIBATA
}

\begin{abstract}
Theoretical and experimental studies are presented on the strength of a composite long column subjected to biaxial bending. In the analysis, the critical conditions for the maximum load are given explicitly and general solutions of strength of composite long columns are obtained for arbitrary cross sections and constitutive relations. In the experimental study, total 16 specimens with 4 types of slenderness are tested for concentric and biaxial eccentric loading. Buildup wide-flange $\mathrm{H}$ $62 \times 50 \times 6 \times 6$ and $9 \phi$ reinforcing bars are encased in $12 \mathrm{~cm} \times 12 \mathrm{~cm}$ concrete cross section. Computed results show good agreements with exact numerical solutions and experiments.
\end{abstract}

Keywords : composite column, biaxial bending, theoretical study, maximum strength, critical condition, experimental study 合成長柱, 2 軸曲げ, 最大耐力, 理論解析, 停留条件, 2 軸偏心圧縮実験

\section{1 序}

2 軸曲げを受ける SRC 長柱の耐力を求めるには, 通常荷重または 変形を徐々に増大させながら耐力が最大となる点を求めるという手 順をとる。それらは，たわみ曲線の形を正弦半波形などで近似する 手法と 1),2), 数值積分や差分法もしくは 1 次元有限要素法によりたわ み曲線を厳密に評価する手法 3) 8)に分類できるが, 特に後者では、荷 重変位曲線上の 1 点を求めるだけでも非線形連立方程式を解かねばな らず, $N-M_{x}-M_{y}$ 相関曲線を求めるには大量の数值計算を必要とする.

著者は先に, 1 軸曲げを受ける SRC 長柱が最大耐力となる条件を 明示的に与えて $N-M$ 相関曲線およびカラムカーブを求める手法を 示した 9). 本論では, 同様の手法を 2 軸曲げ問題に拡張して $N-M_{x}-M_{y}$ 相関曲線およびカラムカーブを求め, 精密な数值解およびかまぼこ球 座を用いた 2 軸偏心圧縮実験の結果と比較検討する.

2 軸曲げを受ける SRC 長柱の実験的研究は, 偏心圧縮実験として Virdi · Dowling1), 松井・森野他 2), 一定軸力のもとで材端モーメント を変動させるJohnson·May10)の研究など数少ない.この種の実験では 材端で回転自由の支持条件を与え得るかが重要なポイントとなる. 全方向に完全な回転自由を実現しようとすれば, 油圧球座 2)や交叉 ナイフエッジ 10)といつた大がかりな材端支持装置を用いねばならな いが, 岩井は RC 長柱の 2 軸偏心圧縮実験で簡易な球面滑り軸受けを
用い，十分な機能を果たし得るとした 11)。一方，一軸偏心圧縮実験 では動作原理が単純明快なナイフエッジやかまぼこ球座が用いられ る.しかし，2 軸偏心問題では中立軸の傾きが曲げモーメント軸と一 致しないので，一般論としてはこれらの材端支持装置を用いるのは 適当ではない. しかし, 直交方向の断面 2 次モーメントの值がそれ ほど異ならない場合は，中立軸の傾きが曲げモ一メント軸とほぼ一 致すると期待できるので, 動作原理が単純明快な材端支持装置とし てかまぼこ球座を用いるのも一つの選択と考えられる.

\section{2 軸力と 2 軸曲げを受ける SRC 長柱の耐力}

ここでは, 文献 9) の手法を 2 軸曲げ問題に拡張し, 一定軸力と 2 軸 曲げを受ける SRC 長柱（以後, 定軸力問題と呼ぶ）の $N-M_{x}-M_{y}$ 相関曲面および 2 軸偏心玨縮を受ける SRC 長柱（以後，偏心圧縮問 題と呼ぶ）のカラムカーブを求める手法を提示する.

2.1 仮定

1) 一定軸力 $N$ のもとで両材端に等しい 2 軸曲げ（ $\left.M_{d x}, M_{d y}\right)$ を受け る単純支持梁, もしくは両端に等しい偏心量 $\left(e_{x}, e_{y}\right)$ の2 軸偏心圧縮 を受ける単純梁を解析対象とする（図 1）.

2) 部材中央での $x, y$ 軸まわり曲率 $\kappa_{x}, \kappa_{y}$ と対応するたわみ $v_{y}, v_{x}$ には

$$
v_{y}=R(L / \pi)^{2} \kappa_{x}, \quad v_{x}=-R(L / \pi)^{2} \kappa_{y}
$$




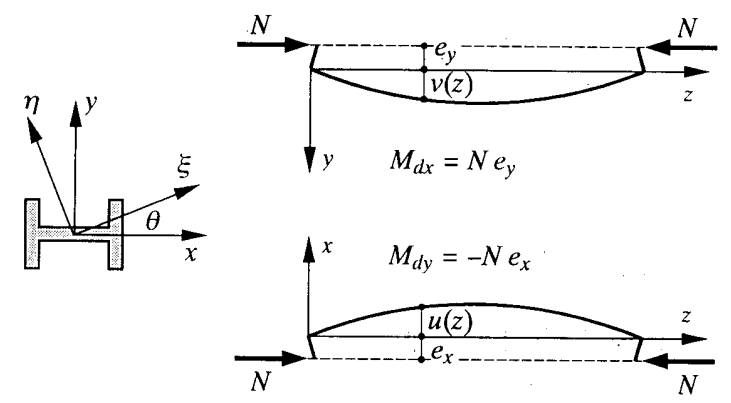

図 1 軸力と2 軸曲げを受ける部材

が成立する. 係数 $R$ は文献 9)での考察より $R=1.05$ とする.

3) 平面保持仮定が成立し, 中央断面での軸ひずみ分布（縮みを正とす る）は, $x, y$ : 図心軸からの距離, $\varepsilon_{C}$ : 図心軸ひずみ, $x, y$ 軸回りの 曲率によって表される。

$$
\varepsilon(x, y)=\varepsilon_{c}-\kappa_{x} y+\kappa_{y} x
$$

4) 材料非線形問題を扱うが，塑性域でのひずみの反転による弾性除荷 は考虑しない.したがって中央断面での応力分布は図心軸ひずみおよ び曲率 $\varepsilon_{c}, \kappa_{x}, \kappa_{y}$ によって一義的に定まる.

5) 対象部材が中実 SRC 部材であり，部材のねじれ変形を無視する.

\section{2 構成則}

中央断面での断面力 $\left(N, M_{x}, M_{y}\right)$ と一般化ひずみ $\left(\varepsilon_{c}, \kappa_{x}, \kappa_{y}\right)$ の 関係は次式で表される．ただし，軸力 $N$ および軸方向応力 $\sigma$ の符号 は圧縮を正とする.

$$
\begin{aligned}
& N\left(\varepsilon_{c}, \kappa_{x}, \kappa_{y}\right)=\int_{A} \sigma\left(\varepsilon_{c}-y \kappa_{x}+x \kappa_{y}\right) d A \\
& M_{x}\left(\varepsilon_{c}, \kappa_{x}, \kappa_{y}\right)=-\int_{A} y \sigma\left(\varepsilon_{c}-y \kappa_{x}+x \kappa_{y}\right) d A \\
& M_{y}\left(\varepsilon_{c}, \kappa_{x}, \kappa_{y}\right)=\int_{A} x \sigma\left(\varepsilon_{c}-y \kappa_{x}+x \kappa_{y}\right) d A
\end{aligned}
$$

$\Delta \sigma=E_{t}\left(\Delta \varepsilon-y \Delta \kappa_{x}+x \Delta \kappa_{y}\right)$ を考慮して式 (3) (5)を増分で表すと

$$
\begin{aligned}
& \Delta N=\bar{A} \Delta \varepsilon-\bar{S}_{x} \Delta \kappa_{x}+\bar{S}_{y} \Delta \kappa_{y} \\
& \Delta M_{x}=-\bar{S}_{x} \Delta \varepsilon+\bar{I}_{x} \Delta \kappa_{x}-\bar{I}_{x y} \Delta \kappa_{y} \\
& \Delta M_{y}=\bar{S}_{y} \Delta \varepsilon-\bar{I}_{x y} \Delta \kappa_{x}+\bar{I}_{y} \Delta \kappa_{y}
\end{aligned}
$$

ここに, $\quad \bar{A}=\int_{A} E_{t} d A, \quad \bar{S}_{x}=\int_{A} y E_{t} d A, \quad \bar{S}_{y}=\int_{A} x E_{t} d A$

$$
\bar{I}_{x}=\int_{A} y^{2} E_{t} d A, \quad \bar{I}_{y}=\int_{A} x^{2} E_{t} d A, \quad \bar{I}_{x y}=\int_{A} x y E_{t} d A
$$

は中央断面での接線弾性係数 $E_{t}$ の積分值である。

定軸力問題では常に $\Delta N=0$ であり,偏心庄縮問題においても最大 耐力時に $\Delta N=0$ 上なるから，式(6) (8)より $\Delta \varepsilon$ を消去すると，

$$
\begin{aligned}
& \Delta M_{x}=\overline{E K}_{x} \Delta \kappa_{x}-\overline{E K}_{x y} \Delta \kappa_{y} \\
& \Delta M_{y}=-\overline{E K}_{x y} \Delta \kappa_{x}+\overline{E K}_{y} \Delta \kappa_{y} \\
& \overline{E K}_{x}=\bar{I}_{x}-\bar{S}_{x}^{2} / \bar{A}, \quad \overline{E K}_{y}=\bar{I}_{y}-\bar{S}_{y}^{2} / \bar{A} \\
& \overline{E K}_{x y}=\bar{I}_{x y}-\bar{S}_{x} \bar{S}_{y} / \bar{A}
\end{aligned}
$$

ここに, $\left(M_{d x}, M_{d y}\right)$ は材端モーメントであり, 偏心圧縮問題では $\left(N e_{y},-N e_{x}\right)$ となる.

$$
\begin{gathered}
\Delta N=0 \text { を考慮して式 }(11),(12) \text { を増分で表せば } \\
\Delta M_{d x}=\Delta M_{x}-N R(L / \pi)^{2} \Delta \kappa_{x} \\
\Delta M_{d y}=-\Delta M_{y}+N R(L / \pi)^{2} \Delta \kappa_{y}
\end{gathered}
$$

\section{4 停留条件}

式(9), (10)を式(13)，(14)に代入し, 最大荷重時は $\Delta M_{d x}=\Delta M_{d y}=$ 0 となることを考慮すると

$$
\left[\begin{array}{cc}
\overline{E K}_{x}-\frac{N}{R}\left(\frac{L}{\pi}\right)^{2} & -\overline{E K}_{x y} \\
-\overline{E K}_{x y} & \overline{E K}_{y}-\frac{N}{R}\left(\frac{L}{\pi}\right)^{2}
\end{array}\right]\left\{\begin{array}{l}
\Delta \kappa_{x} \\
\Delta \kappa_{y}
\end{array}\right\}=\left\{\begin{array}{l}
0 \\
0
\end{array}\right\}
$$

式(15)において $\left(\Delta \kappa_{x}, \Delta \kappa_{y}\right)$ が自明解以外の解を持つためには

$$
\begin{aligned}
& N\left(\varepsilon_{c}, \kappa_{x}, \kappa_{y}\right)=\frac{\pi^{2} \overline{E K}\left(\varepsilon_{c}, \kappa_{x}, \kappa_{y}\right)}{R L^{2}} \\
& \overline{E K}=\frac{\overline{E K}_{x}+\overline{E K}_{y}}{2} \mp \sqrt{\left(\frac{\overline{E K}_{x}-\overline{E K}_{y}}{2}\right)^{2}+\left(\overline{E K}_{x y}\right)^{2}}
\end{aligned}
$$

\section{5 解析手順}

1). $N-M_{x}-M_{y}$ 曲面 (定軸力問題)

式(16)を満たす $\varepsilon_{c}, \kappa_{x}, \kappa_{y}$ を式(3) (5)に代入すれば $N-M_{x}-M_{y}$ 曲面上 の一点が定まる.

\section{2) 偏心圧縮柱のカラムカーブ}

式(11)，(12); (16)より $N R\left(\frac{L}{\pi}\right)^{2}$ を消去して

$$
\begin{aligned}
& M_{x}\left(\varepsilon_{c}, \kappa_{x}, \kappa_{y}\right)-\overline{E K}\left(\varepsilon_{c}, \kappa_{x}, \kappa_{y}\right) \cdot \kappa_{x}=N\left(\varepsilon_{c}, \kappa_{x}, \kappa_{y}\right) \cdot e_{y} \\
& M_{y}\left(\varepsilon_{c}, \kappa_{x}, \kappa_{y}\right)-\overline{E K}\left(\varepsilon_{c}, \kappa_{x}, \kappa_{y}\right) \cdot \kappa_{y}=-N\left(\varepsilon_{c}, \kappa_{x}, \kappa_{y}\right) \cdot e_{x}
\end{aligned}
$$

式(17), (18)を同時に満たす $\varepsilon_{c}, \kappa_{x}, \kappa_{y}$ より対応する材長 $L$ を得る.

$$
L^{2}=\pi^{2} \frac{M_{x} / N-e_{y}}{R \kappa_{x}}
$$

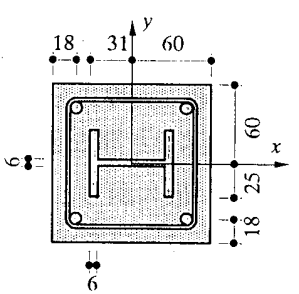

(a)

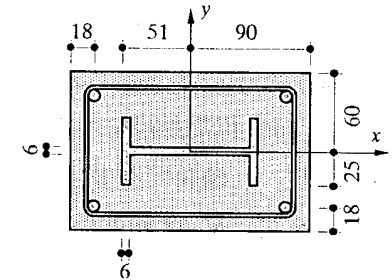

b)
図 2 解析対象 SRC 部材.

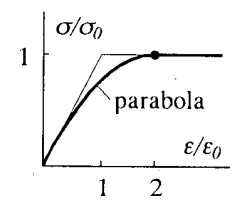

(a) Concrete

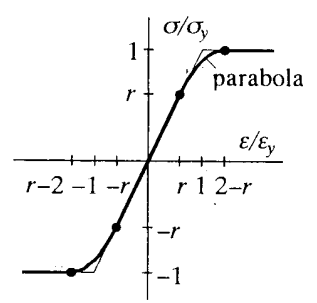

(b) Steel $(r=0.6)$

図 3 パラボラ型構成則 


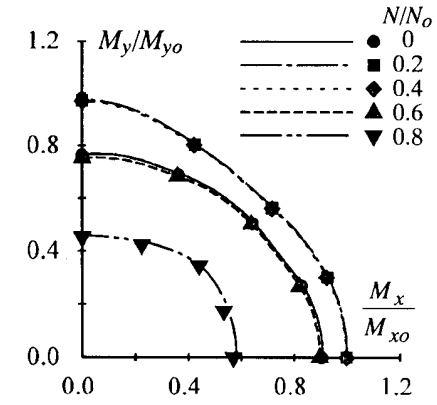

(a) $L / D=0$ (一般化累加強度理論 $)$

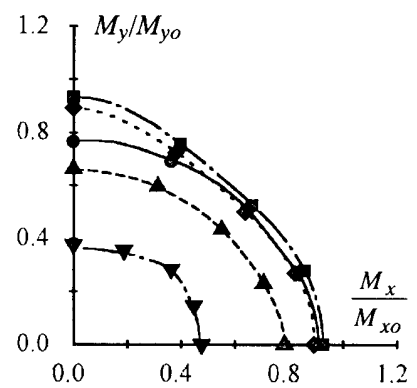

(b) $L / D=4$

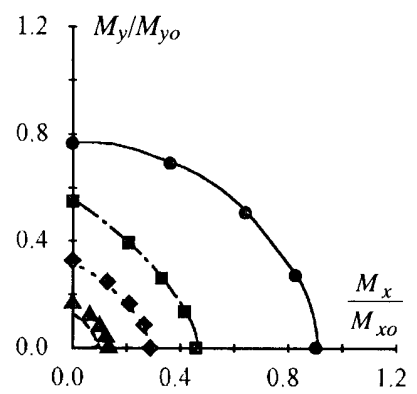

(d) $L / D=20$

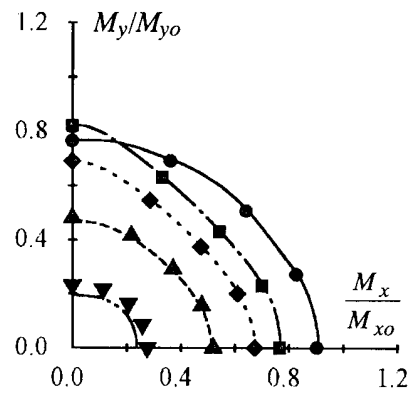

(c) $L / D=10$

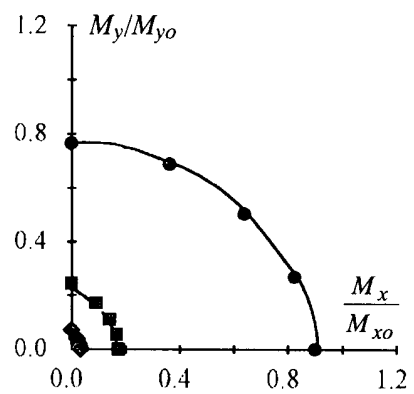

(e) $L / D=30$

図 $4 M_{x}-M_{y}$ 相関曲線（正方形断面材）

\section{$6 N-M_{x}-M_{y}$ 曲面}

図 2(a)の断面形の SRC 長柱について, 軸力比 $N / N_{o}$ を変化させた 場合の $M_{x}-M_{y}$ 相関曲線を図 4 に示す，材料の構成則は図 3 のパラ ボラ型とし，仮定した材料定数を以下に示す.

$\begin{array}{lll}\text { ・コンクリート } & \text { 強度 } & F_{c}=0.374 \mathrm{t} / \mathrm{cm}^{2} \\ & \text { 弾性係数 } & E_{c}=210 \sqrt{5 F_{c}} \mathrm{t} / \mathrm{cm}^{2} \\ \text { ·鉄骨 } & \text { 降伏応力 } & \sigma_{y}=3.17 \mathrm{t} / \mathrm{cm}^{2} \\ \text { ・鉄笳 } & \text { 降伏応力 } & \sigma_{y}=3.33 \mathrm{t} / \mathrm{cm}^{2}\end{array}$

綎，横軸はそれぞれ強軸および弱軸回りの基準曲げ強度（中立軸 が断面中心を通るときの全塑性モーメント)で無次元化されており， 曲線群は本解析結果, 一, 等は差分法によってたわみ曲線を近似 した逐次数值解析結果（付録 2 参照）を示す。この例題における強 軸および弱軸まわりの基準曲げ強さおよび曲げ剛性の比は, それぞ れ $M_{y o} / M_{x o}=1.26$ および $(E I)_{y} /(E I)_{x}=1.11$ である. 上記のような 無次元化によれば, $L / D$ の小さい領域での $M_{x} / M_{x o}-M_{y} / M_{y o}$ 相関 曲面は $45^{\circ}$ 軸に関してほぼ対称の特性を示すが, $L / D$ が大きくなる 之高軸力時に弱軸曲げの特性が卓越し, 曲げの構面が少しでも弱軸 まわりの方向にふれると急激に耐力が低下する.

本解析結果は差分解之良好な対応を示すが，高軸力時にはわずか に安全側の誤差を伴う。これは, 差分解では塑性域でのひずみ反転 による弾性除荷を考慮しているのに対し，本解析が弾性除荷を考慮し 得ないことに起因する.

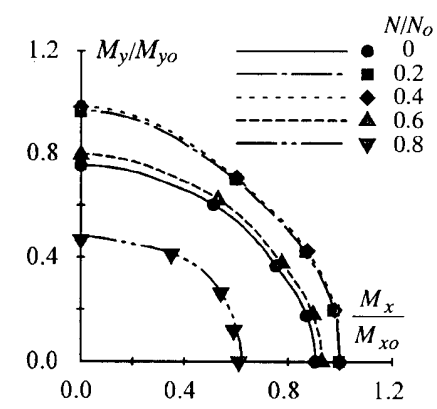

(a) $L / D=0$ (一般化累加強度理論)

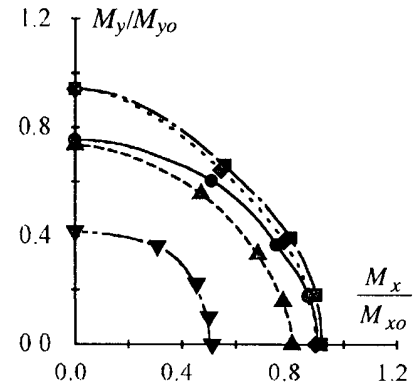

(b) $L / D=4$

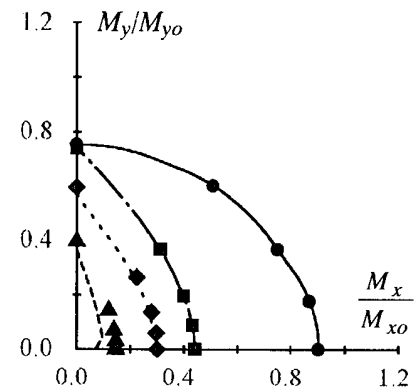

(d) $L / D=20$

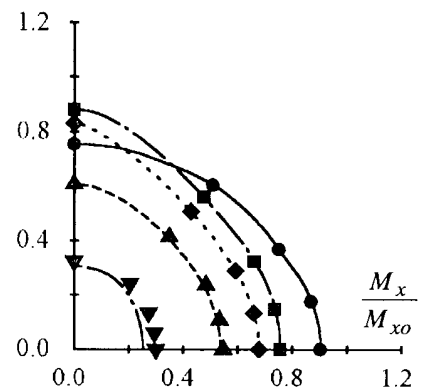

(c) $L / D=10$

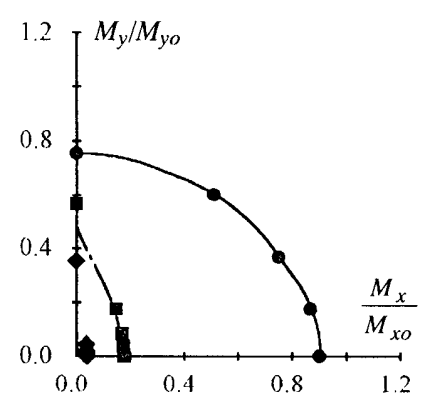

(e) $L / D=30$
図 $5 M_{x}-M_{y}$ 相関曲線（長方形断面材）

弾性除荷は, 中心圧縮に近い載荷条件で断面全体がいったん圧縮 塑性化した後, 座屈変形に伴って曲げ引張側のひずみが戻ることに より生じるから, 偏心量の小さい領域 $(N-M$ 相関曲線上では高軸 力域)で生じやすい. 弾性除荷の効果を無視すると部材剛性を実際 より小さく見積もるので耐力を小さく評価することになる．ここで は示していないが, 弾性除荷を無視した数值解は本解析と一致した.

図 3(b)の断面形を持つSRC 長柱について同様の検討を試みた結 果を図 5 に示す。基準曲げ強さおよび曲げ岡性の比は，それぞれ $M_{y o} / M_{x o}=2.02$ および $(E I)_{y} /(E I)_{x}=2.64$ である. $L / D$ の小さい領 域での $M_{x} / M_{x o}-M_{y} / M_{y o}$ 相関曲面は $45^{\circ}$ 軸に関してほぼ対称の特性 を示し，その傾向は正方形断面材の場合とほぼ同様とみられるが, おおきな $L / D$ に対する弱軸曲げ特性の卓越は著しい.

両例題とも $L / D=30$ に対する相関曲面は一般化累加強度理論解 $(L / D=0$ に対応）に比べて著しく縮小しており，現行鉄骨鉄筋コ ンクリート構造計算規準の $L / D$ の上限值 30 は, それより練長い部 材に関する検討は不要であるという意味で, 妥当な值とみられる.

\section{2 軸偏心圧縮を受ける SRC 長柱の実験 3.1 実験概要}

試験体の概要を表 1, 図 6 に示す. 4 種類の材長と中心圧縮およ び 2 種類の偏心圧縮の組合せで計 16 体の圧縮実験を行った. 表 1 中の基準曲げ強度 $M_{x o}, M_{y o}$ は中立軸が断面中心を通るときの $x, y$ 
表 1 試験体概要

\begin{tabular}{|c|c|c|c|c|c|c|c|c|c|c|c|c|c|c|c|c|c|}
\hline \multicolumn{2}{|c|}{ 試験体 } & Y040 & Y041b & Y041d & Y042 & Y080 & Y081b & Y081d & Y082 & Y120 & $Y 121 b$ & Y121d & $\mathrm{Y} 122$ & Y180 & Y181b & Y181d & Y182 \\
\hline \multicolumn{2}{|c|}{ コ刿一ト強度 $F_{c}\left(\mathrm{t} / \mathrm{cm}^{2}\right)$} & 0.384 & 0.384 & 0.384 & 0.384 & 0.365 & 0.388 & 0.335 & 0.384 & 0370 & 0.381 & 0.370 & 0.381 & 0.384 & 0.388 & 0.335 & 0.365 \\
\hline \multicolumn{2}{|c|}{ 材長 $L(\mathrm{~cm})$} & 48 & 48 & 48 & 48 & 96 & 96 & 96 & 96 & 144 & 144 & 144. & 144 & 216 & 216 & 216 & 216 \\
\hline \multicolumn{2}{|c|}{ 偏心量 $e(\mathrm{~cm})$} & 0 & 0.9 & 0.9 & 2.65 & 0 & 0.9 & 0.9 & 2.7 & 0 & 0.9 & 0.9 & 2.7 & 0 & 0.9 & 0.9 & 2.7 \\
\hline \multicolumn{2}{|c|}{ 降伏軸力 $N_{O}(\mathrm{t})$} & 89.3 & 88.8 & 88.7 & 88.1 & 85.8 & 89.1 & 82.1 & 88.5 & 86.3 & 87.9 & 86.0 & 87.9 & $88.3^{\prime}$ & 88.6 & 81.6 & 85.4 \\
\hline 基準曲 & $M_{X o}(\mathrm{tcm})$ & 143.1 & 141.9 & 142.2 & 141.1 & 137.8 & 142.8 & 131.8 & 142.0 & 138.1 & 140.8 & 137.8 & 141.0 & 141.5 & 141.8 & 131.0 & 136.8 \\
\hline げ強度 & $M_{y o}(\mathrm{tcm})$ & 180.5 & 179.0 & 178.6 & 177.2 & 173.4 & 179.3 & 168.6 & 177.9 & 174.6 & 176.9 & 173.9 & 176.8 & 177.6 & 177.9 & 167.0 & 172.5 \\
\hline \multicolumn{2}{|c|}{ 無次元細長比: $\Lambda$} & 0.181 & 0.181 & 0.181 & 0.181 & 0.360 & 0.363 & 0.358 & 0.362 & 0.543 & 0.543 & 0.543 & 0.542 & 0.816. & 0.818 & 0.805 & 0.814 \\
\hline \multicolumn{2}{|c|}{ 実験耐力 $P_{X}(\mathrm{t})$} & 96.6 & 71.9 & 74.2 & 42.0 & 83.3 & 61.0 & 62.6 & 37.7 & 80.4 & 59.9 & 56.2 & 30.2 & 65.4 & 40.3 & 42.5 & 23.4 \\
\hline \multicolumn{2}{|c|}{ 偏心率 $\mu=N_{o} e / M_{x o}$} & 0 & 0.563 & 0.561 & 1.654 & 0 & 0.562 & 0.561 & 1.683 & 0 & 0.562 & 0.562 & 1.683 & 0 & 0.562 & 0.560 & 1.685 \\
\hline \multicolumn{2}{|c|}{$n=P_{X} / N_{O}$} & 1.081 & 0.809 & 0.836 & 0.477 & 0.971 & 0.685 & 0.763 & 0.426 & 0.912 & 0.682 & 0.653 & 0.343 & 0.740 & 0.454 & 0.520 & 0.273 \\
\hline \multicolumn{2}{|c|}{$m=P_{X} e / M_{X o}$} & 0 & 0.456 & 0.469 & 0.789 & 0 & 0.385 & 0.427 & 0.717 & 0 & 0.383 & 0.367 & 0.577 & 0 & 0.255 & 0.292 & 0.461 \\
\hline
\end{tabular}

軸まわりの全塑性モーメントであり, $\Lambda=\sqrt{N_{o} / N_{E}}$ は基準化細長 比, $N_{E}$ は弾性座屈荷重である.

鉄骨は板厚 $6 \mathrm{~mm}$ の鋼板を溶接して製作し，焼鈍を行った．主筋お よびフープはコンクリートの充填性を最優先して. $9 \mathrm{~mm}, 3 \mathrm{~mm}$ の丸鋼 を用いた，座屈実験で部材に生じるせん断力は小さいので，鋼材と コンクリートの付着性状の影響は小さいと考えられる．鉄骨のフラ ンジおよびウェブより採取した引張試験片，および鉄筋の材料試験 結果を表 2 , 図 7 に示す.コンクリートの調合は表 3 を基準とし, 細 骨材の表面水量に応じて水と細骨材量を補正した。コンクリート材 料の概要を表 4 に示す. コンクリート打設は横打ちとし, 屋外で打 設後 2〜3 日間シートを被せ, 脱型した後は 5 9 週間標準水中養生 し, その後空中養生とした. 実験時の材令は 117〜140日であり, 平 均強度は $374 \mathrm{~kg} / \mathrm{cm}^{2}$, 標準偏差は $16.4 \mathrm{~kg} / \mathrm{cm}^{2}(4.4 \%)$ であった。

載荷・測定システムの概要を図 8 に示す，材端の回転軸が断面の 弱軸と-45゚の角度をなすかまぼこ球座を介して試験体を長柱試験機 に設置した、本実験では、かまぼこ球座の回転軸之試験体断面弱軸 のなす角度はすべて $45^{\circ}$ である．変形の方向が確定しない 2 軸偏心

表 2 鋼材の引張試験結果

\begin{tabular}{llll}
\hline & $7 ラ$ シシ & 主筋 & フ-プ \\
\hline 降伏応力 $\left(\mathrm{t} / \mathrm{cm}^{2}\right)$ & 3.17 & 3.33 & 2.57 \\
引張強度 $\left(\mathrm{t} / \mathrm{cm}^{2}\right)$ & 4.79 & 4.67 & 3.07 \\
伸び率 $(\%)$ & 26.5 & 23.7 & 36.7 \\
\hline
\end{tabular}

表 3 コンクリートの調合（ $1 \mathrm{~m}^{3}$ 当たり） 水セメン比細骨材率水切 砂 砂利 ポリ゙リス $\mathrm{AE}$ 助剤 $70 \% \quad 52 \% \quad 215 \mathrm{~kg} \quad 307 \mathrm{~kg} \quad 863 \mathrm{~kg} 830 \mathrm{~kg} .3 .35,0.35 \ell$

表 4 コンクリート材料の概要

\begin{tabular}{|c|c|}
\hline セメント & 普通ポルトランドセメント 比重 : 3.16 \\
\hline 細骨材 & $\begin{array}{r}\text { 京都府城陽産山砂, 比重 : } 2.56 \\
\text { 吸水率 : } 2.0, \text { 粗粒率 : } 2.80\end{array}$ \\
\hline 粗骨材 & $\begin{array}{c}\text { 大阪府高梘産採石 } \quad \text { 比重 : } 2.67 \\
\text { 吸水率 : } 0.7 \text {, 実績率 : } 56 \text {, 最大粒径 : } 10\end{array}$ \\
\hline $\mathrm{AE}$ 減水剂 & $\begin{array}{lc}\text { ポソリリ N070 } & \text { 比重 : } 1.07 \\
\text { 原液換算使用率 : } \mathrm{C} \times 0.25 \%\end{array}$ \\
\hline
\end{tabular}

圧縮試験でのかまぼこ球座は境界条件として厳密ではなく，試験体 の $x, y$ 軸まわりの曲げ剛性が異なる場合は誤差を伴う可能性がある. しかし, 本実験では $x, y$ 軸まわりの曲げ剛性の差ば $10 \%$ 程度であり, 大きな影響を与えないと判断した．弱軸まわりに座屈する中心圧縮 柱の材端を $45^{\circ}$ 万向に回転拘束した場合の弾性座屈荷重は, 曲げ岡性 比が 1.1 の場合弱軸まわり座屈荷重の約 1.05 倍となる（付録 1 参照）。

中心合わせは, 約 $30 \mathrm{t}$ の圧縮力をかけた状態で部材中央の横たわ みが最小となるように上下端の材端移動機構を調整し，その状態を 中心圧縮の状態とした。偏心圧縮実験では中心圧縮の状態から材端 移動機構を操作して所定の偏心量を与えた.

球座装置をを支点とする測定フレームに設置した 2 個の $1 \mathrm{~cm}$ スト ロークの変位計により材軸方向変位を, $5 \mathrm{~cm}$ もしくは $10 \mathrm{~cm}$ 変位計 により部材中央の横たわみを測定した.

\section{2 実験結果と考察}

\section{1）最大荷重および荷重一横たわみ関係}

実験で得られた最大荷重を表 1 中に「実験耐力」として示す:また, 実験で得られた荷重と軸方向相対変位, および中央点横たわみの関

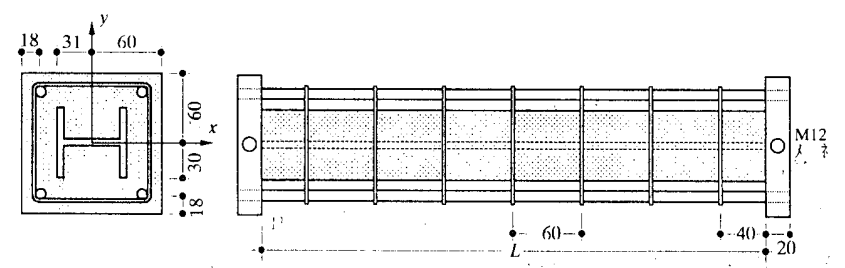

図 6 試験体

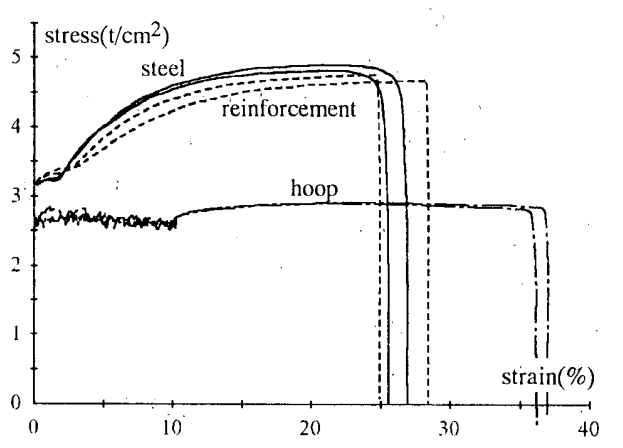

図 7 鋼材の引張試験 


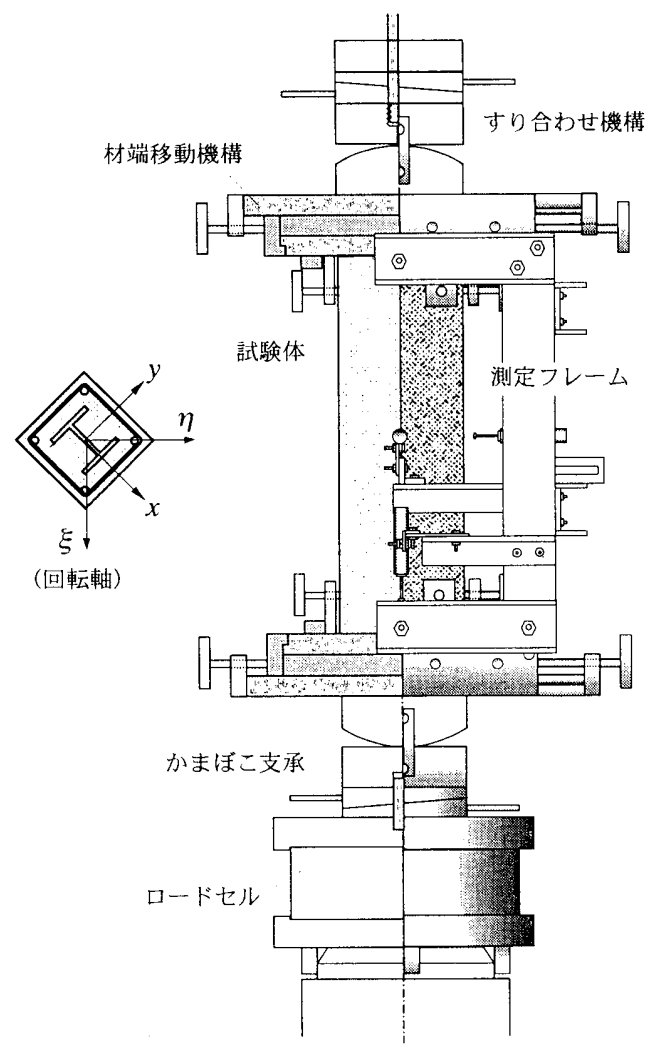

図 8 載荷・計測システム

係を図 9,10 に実線で示す. 縦軸は降伏軸力, 横軸は降伏軸方向変位 および材長で無次元化されている. 図中の破線および 1 点鎖線はた わみ曲線を差分近似して得られた数值解析結果であり (付録 2 参照), 材料の構成則は図 3 のパラボラ型を用いた。破線は材端の回転が 2

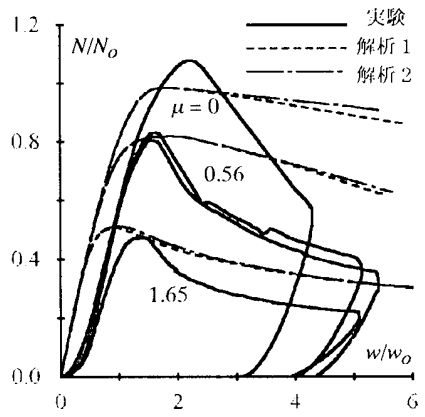

(a) $L / D=4$

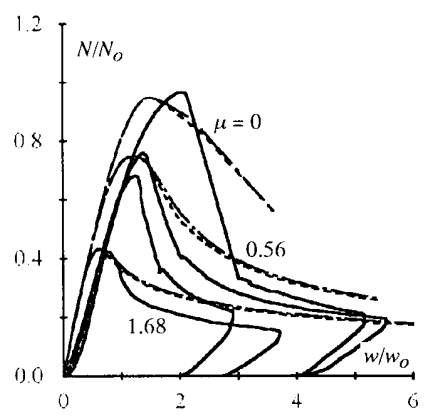

(b) $L / D=8$

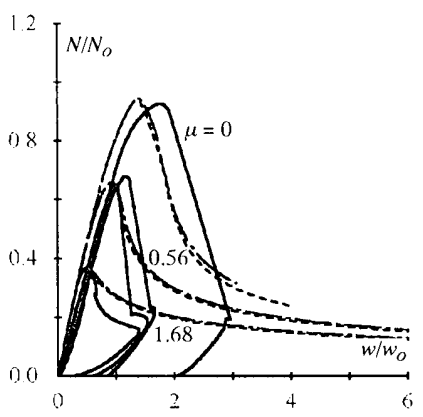

(c) $L / D=12$

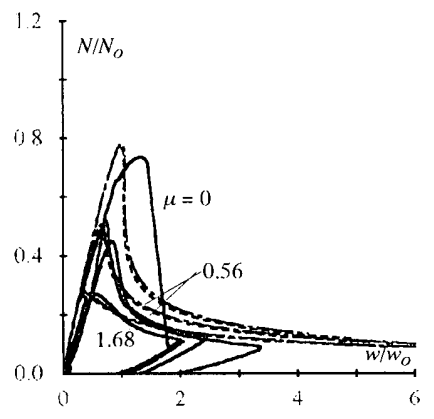

(d) $L / D=18$

図 9 荷重一軸方向变位関係

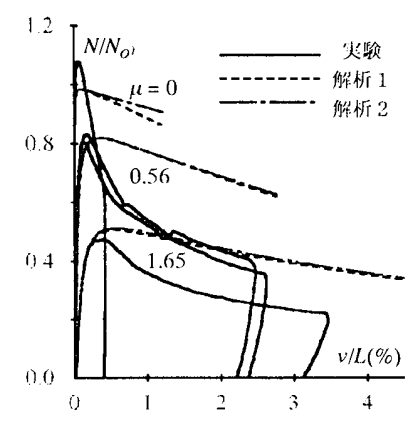

(a) $L / D=4$

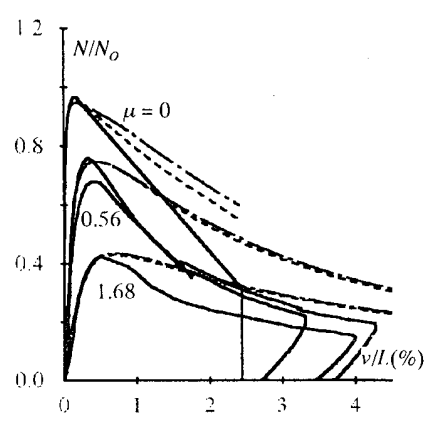

(b) $L / D=8$

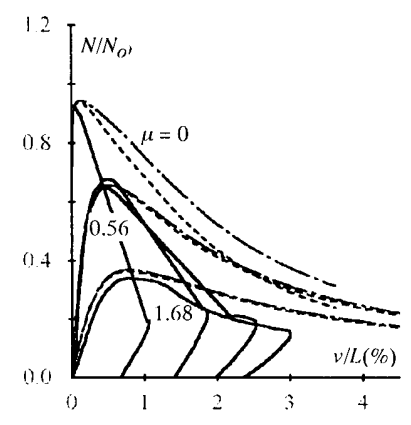

(c) $L / D=12$

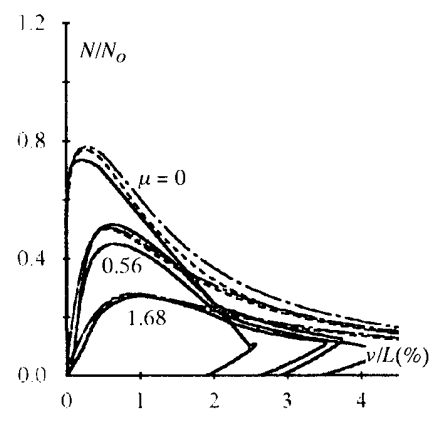

(d) $L / D=18$

図 10 荷重一中央点横たわみ関係 


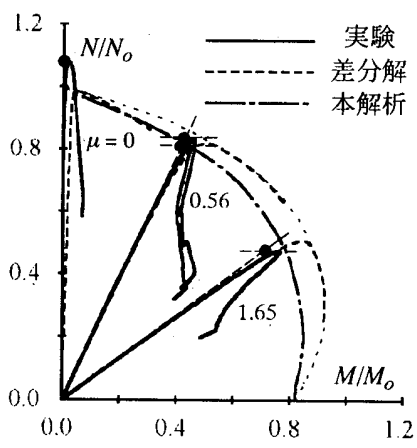

(a) $L / D=4$

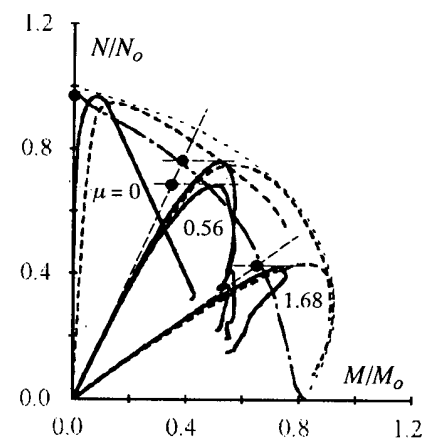

(b) $L / D=8$

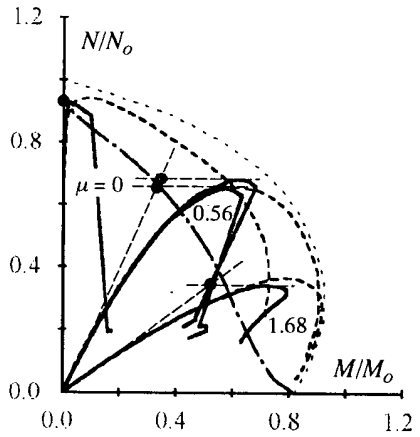

(c) $L / D=12$

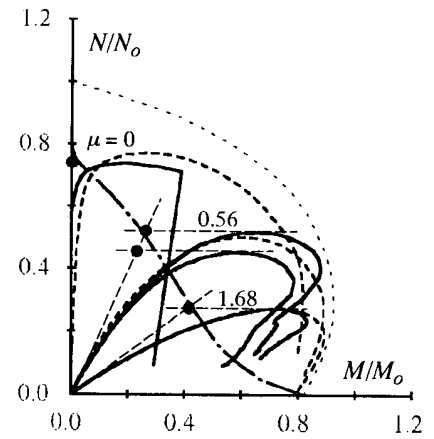

(d) $L / D=18$

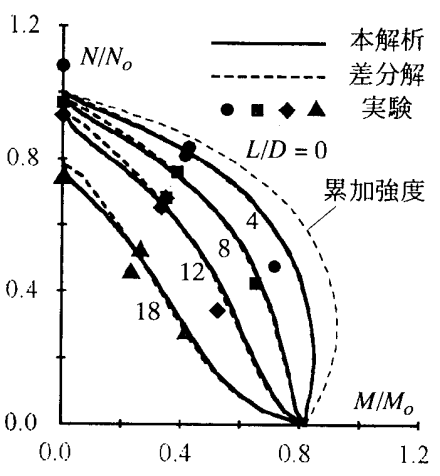

図 $12 N-M$ 相関曲線

図 11 荷重一中央点曲げモーメント関係
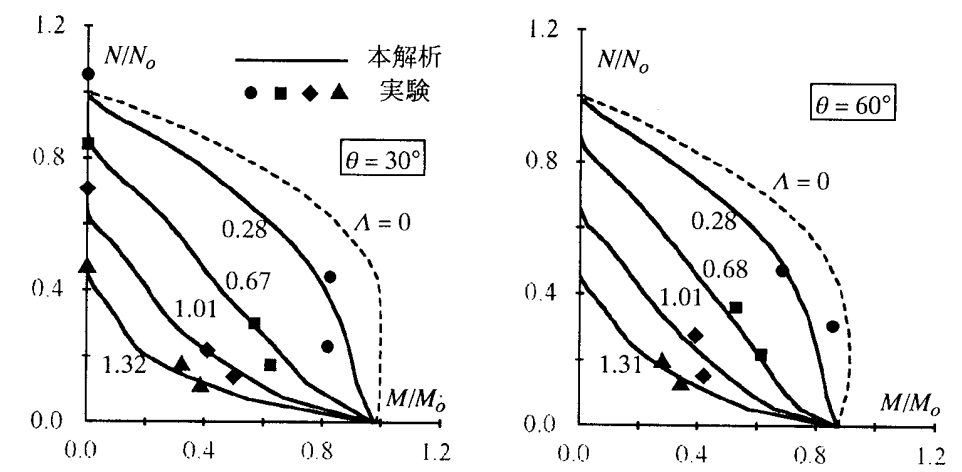

図 13 文献 2)の実験との比較

ここに, $M_{x o}, M_{y o}$ は $x, y$ 軸まわりの基準曲げ強度（前出）, $\theta$ は偏 心方向と $y$ 軸のなす角度で本実験ではすべて $\theta=45^{\circ}$ である. 式(19)の基 準曲げ強さ $M_{o}$ は 2 軸曲げ強度 $\left(M^{*} \cos \theta, M^{*} \sin \theta\right)$ を次式の形で無 次元化する場合の $M_{O}$ に相当する.

$$
\frac{M^{*}}{M_{o}}=\left(\frac{M^{*} \cos \theta}{M_{x o}}\right)^{2}+\left(\frac{M^{*} \sin \theta}{M_{y o}}\right)^{2}
$$

中心圧縮柱では微小な元たわみを与えて数值解析を行ったが，実験 值の処理では元たわみを考虑していない，解析で得られた偏心圧縮柱 の初期軸方向剛性は実験值と良く対応している. $L / D=4 \sim 12$ 場合, 解析では被りコンクリートの剥落による材料劣化が考慮されていな いため, 最大耐力に達した以降は累加強度理論解に漸近していくが, 実験値は最大耐力に達した直後から急激に相関曲線の内側に進み, 中央断面の応力は全塑性状態に達し得ない.

$L / D=18$ の場合は $P-\Delta$ 効果が卓越し, 大変形時にも解析結果は累 加強度曲線に到達しない，実験結果は，最大耐力以後の耐力低下はゆ るやかで, ほぼ累加強度耐力に達してから相関曲線の内側に進む.

図 12 は最大耐力時の材端モーメントと軸力の関係を示す．両軸の 無次元化基準は図 11 と同様である.@，け印などは実験值，実線は 本解析結果, 破線は差分法による数估解, 細点線は一般化累加強度 理論解である. 本解析結果は数值解と良く対応しているが, 高軸力

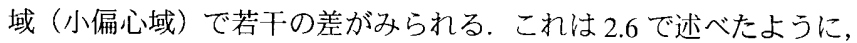
本解析が弾性除荷を考虑し得ないことに起因すると考えられる。本 解析結果は実験值と良好な対応を示し，その妥当性が確認された。

文献 2)では、モーメント軸と部材断面の弱軸の角度が $\theta=0^{\circ}, 30^{\circ}$, $45^{\circ}, 60^{\circ}, 90^{\circ}$ となるような 2 軸偏心圧縮実験が報告されている。ここ ではそれらの内 $\theta=30^{\circ}, 60^{\circ}$ 場合について本解析結果と比較した 結果を図 13 に示す. 本解析結果は実験值と良好な対応を示す.

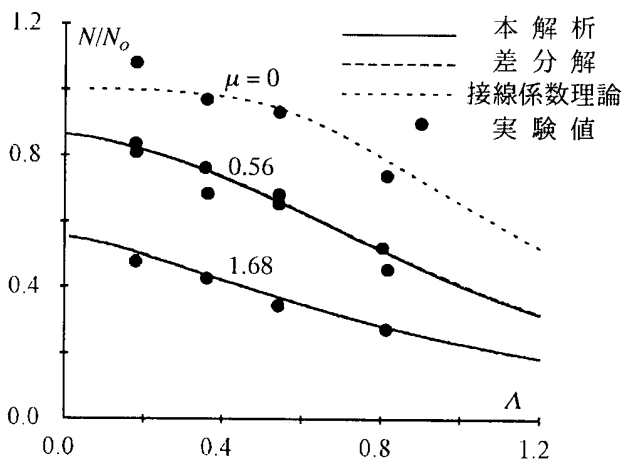

図 14 カラムカーブ

図 14 は偏心圧縮実験における最大耐力と材長の関係を示す．縦軸 は最大荷重と降伏軸力の比, 横軸は基準化細長比 $\Lambda$ を示す. 偏心圧 縮柱に対する実線の本解析結果と破線の数值解はほとんど重なって しまい両者の識別は難しい.の印で示された実験值は偏心圧縮柱に対 する本解析結果, および細点線で示された中心王縮柱に対する接線 係数理論解と良好な対応を示す.

\section{4 結論}

2 軸曲げを受ける SRC 長柱の耐力に関する解析および $45^{\circ}$ 方向 2 軸 偏心圧縮を受ける SRC 長柱の実験を行い, 以下の結論を得た.

1) 2 軸偏心圧縮もしくは定軸力と 2 軸曲げを受ける SRC 長柱の耐力に 関する一般解を得た。

2) パラボラ型の構成法則を用いた本解析結果は，2 軸偏心圧縮実験結果 および差分法による精密解と良好な対応を示した。

3）塑性域でのひずみの反転に伴う弾性除荷の影響は一般に小さいが, 高軸力もしくは小偏心時に若干の影響がでる. 
4) 材長が大きいと弱軸曲げが卓越し, 曲げの構面が少しでも弱軸回り にふれると急激に耐力が低下する．この傾向は，強軸まわりと弱軸回 りの曲げ岡性の比が大きいほど著しい.

5) 材長とせいの比が $L / D=30$ に達すると, $N-M_{x}-M_{y}$ 相関曲面は著し く縮小し, 現行 SRC 規準の $L / D$ の上限值 30 は妥当な値と考えられる.

6) 実験で得られた荷重一横たわみ関係は，最大耐力に達する直前まで はコンクリートの劣化を考虑しない数值解析結果と良好な対応を示し たが，最大耐力に達してからはコンクリートの劣化性状が卓越し，数 值解析結果は危険側の䛊差を与える.

7) $L / D=12$ 以上の偏心圧縮柱ではコンクリートの圧壊. 劣化が始まる 以前に安定限界に達するが, 最大㮽力に達した直後からコンクリート の圧壊, 劣化が卓越し, 中央断面は全塑性状態に達することはない.

8) $L / D=8$ 以下の偏心玨縮柱では安定限界に達する以前にコンクリー トの圧壊. 劣化が始まる可能性がある.しかし, 最大耐力の予測に関 してはコンクリートの劣化現象を考慮する必要はない.

\section{謝辞}

コンクリートの打設に関して便宜を賜ったタイコーKK 藤木英晴 氏，および実験に協力していただいた椇南大学大学院生 入澤 享 氏に厚く感謝します。

\section{参考文献}

1) Virdi, K.S. and Dowling, P.J : The Ultimate Strength of Composite Columns in Biaxial Bending, Proceedings Inst. Civil Engrs., Vol. 55, Part 2, pp.251-272, 1973.03.

2) 松井千秋・森野捷輔 他 : 2 軸偏心圧縮を受ける SRC 長柱の弾塑性性 状に関する研究（その1），日本建築学会大会学術講演梗概集（構造 系），pp.1627-1628，1979.9。（その 2）, 日本建築学会大会学術講演 梗概集（構造系）, pp.1887-1888，1980.9.（その 4）, 日本建築学会 大会学術講演梗概集（满造系），pp.2257-2258，1981.10.

森野捷輔：構造部材㧍よび骨組の弾塑性不安定現象に関する研究, 京 都大学学位請求論文, 1994.07 .

3) Farah, A. and Huggins, M.W. : Analysis of Reinfoeced Concrete Columns Subjected to Longitudinal Load and Biaxial Bending, ACI Journal, Vol. 66, No.7, pp.569-575, 1969.08.

4) Chen, W.F. and Shoraka, M.T. : Analysis and Design of of Reinforced Columns und Biaxial Loading, Preliminary Report, IABSE Symposium, Quebec, pp.187-195, 1974.

5) Virdi, K.S. and Dowling, P.J : :The Ultimate Strength of Biaxially Restrained Columns, Proceedings Inst. Civil Engrs., Vol. 61, Part 2, pp.41-58, 1976.03.

6) May, I.M. and Johnson, R.P. : Inelastic Analysis of Biaxially Restrained Columns, Proceedings Inst. Civil Engrs., Vol. 65, Part 2, pp.323-337, 1978.06.

7) Al-Noury, S.I. and Chen, W.F. : Finite Segment Method for Biaxially Loaded RC Columns, Jour. Str. Div, ASCE, Vol.108, No.ST4, pp.780-799, 1982.04.

8) 岩井 哲・南 宏一・若林 實: 2 軸偏心圧縮を受ける鉄筋コンクリ 一ト長柱の終局耐力ーその 2 実験挙動の解析的考察, 日本建築学会 構造系諭文報告集，No.378，pp.67-74，1987.08.

9) 柴田道生 : 任意形状の鉄骨を持つ SRC 長柱の N-M 相関曲線, 日本建 築学会構造系論文集, No.493, pp.139-146，1997.03.

10) Johnson, R.P. and May, I.M. : Tests on Restrained Composite Columns, The Structural Engineer, Vol. 56B, No. 2, pp.21-28, 1978.06.

11）岩井 哲・南 宏一・若林 實: 2 軸偏心圧縮を受ける鉄筋コンクリ 一ト長柱の終局耐力ーその 1 正方形断面柱の載荷実験, 日本建筑学 会棈造系論文報告集，No.367，pp.59-68，1986.09.

\section{付録 1 斜め方向に回転支持された部材の弾性座屈}

部材断面の弱軸 ( $x$ 軸) に対して角度 $\theta$ 傾いた $\xi$ 軸まわりに回転支 持された部材の弾性座屈荷重を求める（図 $\mathrm{A} 1$ ）。

釣り合い微分方程式

$$
E i_{x} v_{y}{ }^{\prime \prime \prime}(z)+P v_{y}{ }^{\prime \prime}(z)=0, \quad E I_{y} v_{x}{ }^{\prime \prime \prime}(z)+P v_{x}{ }^{\prime \prime}(z)=0
$$

の一般解は, 変形の対称性を考慮して部材中央を原点にとれば,

$v_{x}(z)=A\left\{\cos \left(k_{y} z\right)-\cos (\alpha \zeta)\right\}, \quad v_{y}(z)=B\left\{\cos \left(k_{x} z\right)-\cos \xi\right\}$ (A2)

$$
k_{x}^{2}=P /\left(E I_{x}\right), \quad k_{y}^{2}=P /\left(E I_{y}\right), \quad \xi=k_{x} L / 2, \quad \alpha=k_{y} / k_{x}
$$

材端で $\xi$ 軸まわりに回転自由: $v^{\prime \prime}(L / 2)=0, \eta$ 軸まわり回転拘束： $u^{\prime}(L / 2)=0$ の境界条件より

$$
\left[\begin{array}{cc}
\alpha^{2} \mu \cos (\alpha \xi) & -\lambda \cos \xi \\
\alpha \lambda \sin (\alpha \xi) & \mu \sin \xi
\end{array}\right]\left(\begin{array}{l}
A \\
B
\end{array}\right)=\left(\begin{array}{l}
0 \\
0
\end{array}\right)
$$

$$
\lambda=\cos \theta, \mu=\sin \theta
$$

$A, B$ が 0 以外の值を持つには $\zeta$ は次式の根として得られる.

$$
\alpha \tan ^{2} \theta \tan \zeta+\tan (\alpha \zeta)=0
$$

弾性座屈荷重 $P_{c r}$ は Euler 荷重を $P_{E}$ とおけば

$$
P_{c r}=P_{E}(2 \xi / \pi)
$$

$\theta=45^{\circ}$ の場合, $I_{y} / I_{x}$ と $P_{c r} / P_{E}$ の関係は次表となる.

表 A1 $45^{\circ}$ 方向に支持された部材の弾性座屈荷重

\begin{tabular}{c|cccc}
\hline$I_{y} / I_{x}$ & 4 & 2 & 1.5 & 1.1 \\
\hline$P_{c r} / P_{E}$ & 1.479 & 1.298 & 1.188 & 1.047 \\
\hline
\end{tabular}

\section{付録 2 たわみ曲線の差分近似による逐次数值解析}

部材長の $1 / 2$ を $n$ 分割し（図 $\mathrm{A} 2$ ），各節点での曲率を $\xi, \eta$ 軸方向 変位 $u_{i}, v_{i}$ で差分表示すれば

$$
\begin{array}{ll}
\kappa_{\xi i}\left(=-v_{i}^{\prime \prime}\right)=\left(-v_{i-1}+2 v_{i}-v_{i+1}\right) / s^{2} & 0<i<n \\
\kappa_{\eta i}\left(=u_{i}^{\prime \prime}\right)=\left(u_{i-1}-2 u_{i}+u_{i+1}\right) / s^{2} & 0<i<n \\
\kappa_{\xi n}=2\left(v_{n}-v_{n-1}\right) / s^{2}, \quad \kappa_{\eta n}=2\left(u_{n-1}-u_{n}\right) / s^{2}
\end{array}
$$

各節点での断面力と変形の関係は

$$
\begin{aligned}
& P=\int_{A} \sigma\left\{\varepsilon_{c}-(\lambda y-\mu x) \kappa_{\xi}+(\lambda x+\mu y) \kappa_{\eta}\right\} d A \\
& M_{x}\left(\varepsilon_{c}, \kappa_{\xi}, \kappa_{\eta}\right)=-\int_{A} y \sigma\left\{\varepsilon_{c}-(\lambda y-\mu x) \kappa_{\xi}+(\lambda x+\mu y) \kappa_{\eta}\right\} d A \\
& M_{y}\left(\varepsilon_{c}, \kappa_{\xi}, \kappa_{\eta}\right)=\int_{A} x \sigma\left\{\varepsilon_{c}-(\lambda y-\mu x) \kappa_{\xi}+(\lambda x+\mu y) \kappa_{\eta}\right\} d A
\end{aligned}
$$

節点 $i$ での $\xi, \eta$ 軸回りの釣り合いより,

$$
M \xi_{i}=P\left(e+v_{i}\right), \quad M_{\eta i}=-P u_{i}
$$

式(A9)に式(A6) (A8)を代入し, 各節点での $\varepsilon_{c i}$ を消去した後, $2 n$ 元非線形連立方程式を解くことにより，与えられた $v_{n}$ に対する $u_{i}$ : $i=1 \ldots n, v_{i}: i=1 \ldots n-1$ および $P$ が求まる.
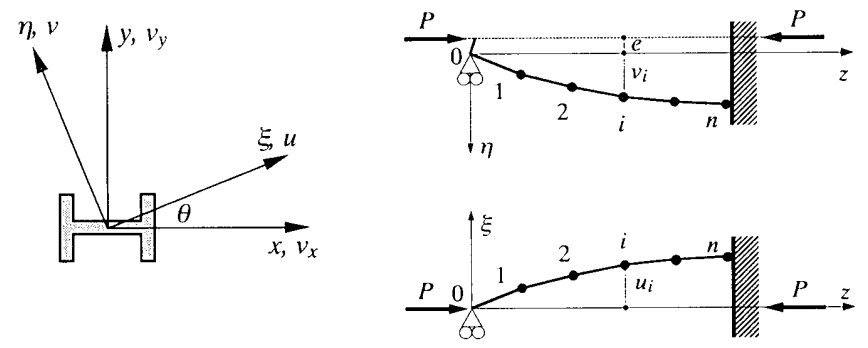

図 A1 座標系 